\title{
Note on Athenian Money
}

The basic unit of currency in ancient Athens was the drachma (divided into six obols). One hundred drachmae were reckoned as one mina, and sixty minae made up one talent. Values may be expressed either in minae and talents, or in hundreds or thousands of drachmae, which can occasion some confusion. As regards modern equivalences, a rule of thumb frequently resorted to is that a drachma was regarded throughout our period (mid-fifth to late fourth centuries $\mathrm{BC})$ as a good daily wage for a skilled craftsman. If, however, one converts that into the going current rate for such an individual ( $f 50$ 60 a day would be a very conservative estimate!), one ends up with truly monstrous totals for certain commodities or services when reckoned in minae or talents (a talent, for instance, must be reckoned as at least $£ 300,000)$; so attempts at strict modern monetary equivalents for ancient prices are largely unreal. 